\title{
PENGARUH BUDAYA, SOSIAL, PRIBADI DAN MOTIVASI TERHADAP PERSEPSI KONSUMSI PANGAN POKOK NON BERAS MASYARAKAT DI KOTA DEPOK
}

\author{
Ahmad Jazilil Mustopa, Elpawati* dan Edmon Daris
}

\begin{abstract}
ABSTRAK
Keberhasilan pembangunan di sektor pertanian suatu Negara harus tercermin oleh kemampuan Negara tersebut dalam swasembada pangan, atau paling tidak ketahanan pangan. Saat ini ketahanan pangan saja dianggap tidak cukup untukmewakili identitas Negara agraris, Namun pemerintah juga kesulitan untuk mencapai target swasembada pangan hingga akhirnya mengeluarkan beberapa kebijakan untuk mencapai hal tersebut. Salah satu kebijakannya adalah program diversifikasi pangan yang tercermin dalam Peraturan Presiden Republik Indonesia No.22 tahun 2009 yang menetapkan kebijakan percepatan penganekaragaman konsumsi pangan berbasis sumberdaya lokal. Kebijakan ini dipersiapkan untuk mengurangi permasalahan yang timbul sekarang yaitu karena hampir seluruh masyarakat Indonesia menggunakan beras sebagai makanan pokoknya. Sedangkan laju produksi beras dengan tingkat permintaan konsumen semakin tidak seimbang. Padahal, jika dilihat dari segi pemenuhannya masih banyak sumber pemenuhan kebutuhan pokok selain beras yang bisa dikembangkan. Tujuan dari penelitian ini adalah : 1) Mengidentifikasi karakteristik responden di Kota Depok. 2) Menganalisis pengaruh variabel budaya, sosial, pribadi, dan motivasi terhadap persepsi konsumsi pangan pokok non beras masyarakat di Kota Depok. 3). Menganalisis pengaruh variabel budaya, sosial, pribadi, dan motivasi secara bersama-sama terhadap persepsi konsumsi pangan pokok non beras masyarakat di Kota Depok.
\end{abstract}

Kata Kunci : pengaruh, budaya, sosial, pribadi, motivasi, persepsi, konsumsi pangan pokok non beras

\section{ABSTRACT}

The successes of development within an agricultural sector in a country should be reflected by the ability of food self-sufficiency, at least in the food security. Currently, the food security is not considerably sufficient to represent the identity of an agricultural country. Yet, the government also have difficulties to reach the target of food self-sufficiencies until they finally make some policies to achieve the aim. One of the policies is a food diversification program reflected in the Presidential Regulation of Indonesia No. 22 in 2009 that regulatesfood 
consumption diversification acceleration policy based on local resources. It is prepared to reduce the problems that appear recently because most of Indonesian use rice as their staple foods. Meanwhile, the rice production is unbalanced if compared with the level of consumer demands. In fact, if it is considered in terms of fulfillment, in addition to rice, there are still a lot of staple foods that can be developed. The aims of this research are: 1) Identifying the characteristics of respondents in Depok city. 2) Analyzing the influences of the cultural, social, personal, and motivation variables to the perception of non-rice food consumption societies in Depok city. 3). Analyzing the influences of the cultural, social, personal, and motivation variables simultaneously to the perception of non-rice food consumption societies in Depok city.

Keywords :Influence, Cultural, Social, Personal, Motivation, Perception, Staple Food Consumption Non Rice

\section{PENDAHULUAN}

Presiden pertama Indonesia, Ir. Soekarno, seperti tertera dalam prasasti peresmian gedung IPB (1952), pernah menegaskan bahwa "Pangan merupakan soal matihidupnya suatu bangsa, apabila kebutuhan pangan rakyat tidak dipenuhi maka malapetaka, oleh karena itu perlu usaha secara besarbesaran, radikal dan revolusioner" (Arifin: 2007). Dalam konteks kebutuhan manusia yang paling mendasar, pangan selalu mendapat prioritas utama, terlebih masalah pangan ini berkaitan dengan hajat hidup orang banyak dan bahkan menjadi salah satu standar tingkat kesejahteraan masyarakat sebuah Negara. Wajar bila akhirnya pangan ini tidak hanya menjadi sebuah kebutuhan dasar tetapi sudah masuk ke ranah geopolitik dan persaingan ekonomi global. Dalam keadaan krisis dan kritis, sesungguhnya semuanya masih boleh ditawar atau ditunda, kecuali makanan. Itulah sebabnya, pangan dapat dikatakan merupakan ibu dari semua kebutuhan, artinya di sanalah bermuara semua kehidupan dan penghidupan (Hafsah: 2006).

Saat ini tidak semua Negara mampu memenuhi semua kebutuhan terhadap pangan sehingga kemudian berkembang praktek perdagangan Internasional, tetapi kondisi ini sekaligus juga berkembang menjadi ketergantungan sebuah Negara terhadap Negara lain. Negara dengan luasan yang sempit, apalagi ditambah dengan kondisi geografis yang tidak ideal dapat membuat suatu Negara menjadi sangat tergantung pada suplai pangan dari Negara lain. Dalam kaitan denganhal tersebut maka kedaulatan pangan menjadi isu yang sangat penting (Yuwono:2011).

Kedaulatan pangan sendiri menurut Undang-undang Pangan nomor 18 Tahun 2012 dijelaskan sebagai hak negara dan bangsa yang secara mandiri menentukan kebijakan pangan yang menjamin hak atas pangan bagi rakyat dan yang memberikan hak bagi masyarakat untuk menentukan sistem pangan yang sesuai dengan potensi sumber daya local. Selanjutnya yang disebut 
dengan pangan dalam undangundang tersebut adalah segala sesuatu yang berasal dari sumber hayati produk pertanian, perkebunan, kehutanan, perikanan, peternakan, perairan, dan air, baik yang diolah maupun tidak diolah yang diperuntukkan sebagai makanan atau minuman bagi konsumsi manusia, termasuk bahan tambahan pangan, bahan baku pangan, dan bahan lainnya yang digunakan dalam proses penyiapan, pengolahan, dan atau pembuatan makanan atau minuman.

Secara garis besar, kedaulatan pangan di Negara ini menurut UU no 18 tahun 2012 tersebut bisa dikatakan belum terlaksana, tercermin dari masih banyak masyarakat yang belum terjamin haknya atas pangan, dan juga masih banyak masyarakat yang belum bisa mengakses kebutuhan pangan berbasis sumberdaya lokal. Kemandirian dalam menentukan penyediaan pangan saat ini juga masih bergantung pada Bangsa lain dalam pemenuhannya, dengan fakta kondisi lahan yang terhampar untuk pertanian didukung geografis yang ideal. Kondisi-kondisi ini diperparah dengan ketergantungan hampir seluruh masyarakat Indonesia terhadap satu bahan pangan pokok, yakni beras.

Permasalahan yang timbul sekarang adalah hampir seluruh masyarakat Indonesia menggunakan beras sebagai makananpokoknya. Sedangkan laju produksi beras dengan tingkat permintaan konsumen semakin tidak seimbang. Padahal, jika dilihat dari segi pemenuhannya masih banyak sumber pemenuhan kebutuhan pokok selain beras yang bisa dikembangkan.

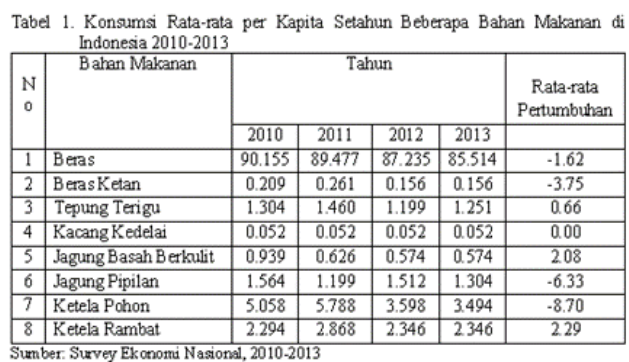

Pada tabel 1 di atas walaupun tingkat konsumsi beras rata-rata perkapitanya menurut rata-rata pertumbuhannya menurun, tetapi jumlahya yang masih besar hingga kini masih menjadi masalah. Perbandingan tingkat konsumsi beras dengan sumber pangan lainnya masih terlihat jauh. Jenis umbi-umbian ketela rambat memang mengalami pertumbuhan dalam rata-rata konsumsi tapi secara kuantitas masih kecil. Terlebih jika dibandingkan dengan tingkat produksi beras nasional seperti pada tabel 2. Dimana ada ketimpangan jumlah konsumsi dan produksi yang didalamnya tingkat produksi lebih rendah daripada tingkat konsumsi. Berbeda halnya dengan komoditi non beras yang tingkat produksinya lebih tinggi daripada tingkat konsumsi. Begitu dalamnya tertanam dalam emosi setiap orang Indonesia bahwa beras itu adalah makanan pokok sehingga hampir tidak mungkin lagi menemukan barang substitusinya. Kelangkaan beras di pasar walau dalam jumlah yang tidak terlalu banyak amat gampang memicu kegelisahan masyarakat. Dengan begitu, berkembanglah trauma dalam masyarakat dan kalangan politik bahwa beras itu sangat strategis dalam menjaga kestabilan sosial ekonomi dan politik sejak masa Orde Lama.

Realitas yang ada, menurut tim peneliti IPSK-LIPI dalam Hermen Malik (2013) mengatakan bahwa 
dengan kondisi jumlah penduduk Indonesia tahun 2010 saja telah mencapai 237,55 juta Jiwa. Laju pertumbuhan $1,3 \%$ per tahun antara tahun 2005-2010, 1,18\% per tahun pada tahun 2010-2015, dan diprediksi menjadi $0,82 \%$ per tahun pada tahun 2025-2030, maka jika konsumsi per kapita tetap $139 \mathrm{Kg} / \mathrm{kapita} / \mathrm{tahun}$, pada tahun 2030 nanti kita memerlukan 59 juta ton beras. Sementara pada tahun 2008 saat Indonesia mencapai swasembada beras, Indonesia baru memproduksi beras sekitar 40 juta ton atau sekitar 60,28 juta ton gabah kering giling. Ketergantungan akan beras memang seharusnya tidak menjadi masalah jika pemenuhannya dilakukan secara mandiri dan tidak tergantung terhadap Negara lain, akan tetapi hal ini terjadi sebaliknya. Bahkan menurut Arifin (2007), permaslahan tataniaga beras di Indonesia bersifat multidimensi karena beras merupakan komoditas strategis, pangan pokok bagi sebagian besar masyarakat.

Kebijakan tata niaga beras tidak saja bermuatan ekonomi, namun juga sosial dan politik. Sejalan dengan dinamika perkembangan ekonomi Nasional dan global, sosial dan politik di dalam Negeri, tata niaga beras juga berkembang semakin dinamis. Akibatnya permasalahan yang berkembang pun menjadi semakin kompleks, terutama yang menyangkut disparitas harga beras, baik antar waktu, maupun antar daerah (regional). Disparitas harga beras tidak saja terjadi secara vertikal antar pelaku, tetapi juga horizontal antar berbagai tingkatan pasar yang ada.

Dalam rencana strategis Kementrian Pertanian 2010-2014, pemerintah

berupaya

menyeragamkan konsumsi pangan masyarakat dan tidak selalu bertumpu pada beras. Penyeragaman pangan masyarakat diharapkan menambah nilai konsumsi gizi di masyarakat dan juga menanggulangi meningkatnya konsumsi akan beras, di tengah sebagian pemenuhannya masih mengandalkan impor. Kebijakannya ini dikenal dengan program diversifikasi pangan yang merupakan salah satu strategi untuk mencapai ketahanan pangan. Salah satu upaya peningkatan diversifikasi pangan adalah percepatan penganekaragaman konsumsi pangan yaitu tercapainya pola konsumsi pangan yang beragam, bergizi seimbang dan aman, yang dicerminkan oleh tercapainya skor Pola Pangan Harapan (PPH) sekurang-kurangnya 93,3 pada tahun 2014.

Konsumsi umbi-umbian, sayuran, buah-buahan, pangan hewani ditingkatkan dengan mengutamakan produksi lokal, sehingga konsumsi beras diharapkan turun sekitar 1,5 persen per tahun.

\section{METODE PENELITIAN}

\section{Lokasi dan Waktu Penelitian}

Penelitian ini menggunakan desain cross sectional study, yaitu penelitian yang dilakukan dalam satu waktu tertentu dan tidak berkelanjutan. Lokasi penelitian mencakup seluruh Kecamatan di Kota Depok. Waktu penelitian berlangsung dari bulan April sampai bulan November 2014, dan bulan Maret 2015.

\section{Jenis dan Sumber Data}

Data yang digunakan dalam penelitian ini adalah data primer dan 
data sekunder. Data primer meliputi karakteristik responden seperti usia, pekerjaan, pendapatan dan lainnya, serta data variabel budaya, sosial, pribadi dan motivasi yang mempengaruhi persepsi konsumsi terhadap pangan pokok nonberas. Data inidiperoleh dari hasil wawancara langsung dengan responden melalui observasi lapang dengan panduan kuesioner. Data sekunder meliputi gambaran umum wilayah penelitian, seperti kondisi geografis, data penduduk, tingkat pendidikan, agama dan data potensi pangan lokal dari sumber-sumber yang relevan seperti buku, jurnal dan data dari instansi terkait seperti dari badan pusat statistik.

\section{Metode Pengambilan Sample}

Penentuan responden dilakukan dengan metode purposive sampling. Populasi nya yaitu seluruh keluarga yang berada di wilayah Kota Depok. Contoh penelitian, keluarga yang tinggal di kecamatan lokasi penelitian dengan jumlah sampel sesuai proporsi jumlah keluarga di Kecamatan tersebut, sementara responden yang dipilihialah ibu, karena sosok ibu adalah pusat hidup rumah tangga, pemimpin dan pencipta kebahagian anggota keluarga. Sosok ibu bertanggungjawab menjaga dan memperhatikan kebutuhan anak, mengelola kehidupan rumah tangga, memikirkan keadaan ekonomi dan makanan anak-anaknya, memberi teladan akhlak, serta mencurahkan kasih sayang bagi kebahagian sang anak (Tarbiyah: 2009). Ibu juga senantiasa mengurus kebutuhan dapur dan memiliki pengaruh paling besar dalam menentukan pola konsumsi pangan keluarga sehingga ibu menjadi responden dalam penelitian ini.

Penentuan lokasi penelitian menggunakan teknik rumpun sampling/area sampling (Cluster Sampling) yaitu teknik sampling daerah yang digunakan untuk menentukan sampel bila objek yang akan diteliti atau sumber data sangat luas, misalnya penduduk dari suatu Negara, Propinsi atau Kabupaten. Untuk menentukan penduduk mana yang akan dijadikan sumber data, maka pengambilan sampelnya berdasarkan daerah populasi yang telah ditetapkan (Sugiyono:2012). Populasi pada sampling ini dibagi ke dalam kelompok kewilayahan kemudian memilih wakil-wakil tiap kelompok. Seperti populasi di Kota Depok yang sampelnya diambil dari masingmasing Kecamatan dengan jumlah sesuai dengan presentase keluarga di Kecamatan tersebut.

Teknik pengambilan responden yaitu melalui teknik random sampling. Ukuran sampel yang diperlukan dalam penelitian ini adalah menggunakan rumus Slovin. Rumus Slovin (Seivilla et. al. :1993), sebagai berikut:

$$
\begin{aligned}
& \qquad n=\frac{N}{1+n e^{2}} \\
& \text { dimana } \\
& \mathrm{n} \text { : jumlah sampel } \\
& \mathrm{N} \text { : jumlah populasi } \\
& \text { e: batas toleransi kesalahan (error tolerance) } \\
& \mathrm{n}=\frac{570.491}{1+570.491(0,1)^{2}}=99,98
\end{aligned}
$$

Responden yang diambil adalah sampel dari masing-masing kecamatan dihitung berdasarkan persentase jumlah keluarga di masing-masing Kecamatan tersebut. Instrumen Penelitian Instrumen penelitian disusun berdasarkan 
definisi operasional dari masingmasing variabel penelitian. Definisi operasional adalah seperangkat petunjuk yang lengkap tentang apa yang harus diamati dan bagaimana mengukur suatu variabel atau konsep.

Dalam penelitian ini digunakan empat variabel bebas dan satu variabel terikat, yaitu:
a. Variabel Budaya
b. Variabel Sosial
c. Variabel Pribadi
d. Variabel Motivasi
e. Variabel Persepsi Konsumen

Instrumen penelitian dalam bentuk kuesioner disusun dengan pertanyaan terbuka dan tertutup. Pada pertanyaan tertutup menggunakan skala likert. Skor untuk skala likert dalam penelitian ini adalah:

$1=$ Sangat tidak setuju $=$ STS

$2=$ Tidak Setuju $=$ TS

$3=$ KurangSetuju $=$ KS

$4=$ Setuju $=$ S

$5=$ Sangat Setuju $=$ SS

Pertanyaan terbuka pada penelitian ini berupa uraian tertulis sehingga responden bisa memberikan pendapat terkait variabel-varibel bebas dan variabel tidak bebas yang terdapat pada penelitian ini.

\section{Metode Pengolahan dan Analisis Data}

\section{Analisis Data Kuantitatif}

Analisis kuantitatif adalah analisis data yang menggunakan data berbentuk angka-angka yang diperoleh sebagai hasil pengukuran atau penjumlahan (Nurgiyantoro $\mathrm{dkk}$, 2004). Untuk mendapatkan data kuantitatif, digunakan skala

Likert yang diperoleh dari daftar pertanyaan yang digolongkan ke dalam dua pilihan jawaban, yaitu: a. Untuk jawaban "Sangat Setuju" sangat tidak setuju diberi nilai $=5$

b. Untuk jawaban "Setuju" tidak setuju diberi nilai $=4$

c. Untuk jawaban "Kurang Setuju" tidak setuju diberi nilai $=3$

d. Untuk jawaban "Tidak Setuju" tidak setuju diberi nilai $=2$

e. Untuk jawaban "Sangat Tidak Setuju" tidak setuju diberi nilai $=1$

\section{Analisis Regresi Berganda}

Analisis regresi berganda dalam penelitian ini bertujuan untuk mengetahui pengaruh variabel budaya, sosial, pribadi dan motivasi terhadap persepsi konsumsi pangan pokok non beras. Adapun bentuk umum persamaan regresi berganda yang digunakan dalam penelitian ini adalah:

$\mathrm{Y}=\mathrm{a}+\mathrm{b} 1 \mathrm{X} 1+\mathrm{b} 2 \mathrm{X} 2+\mathrm{b} 3 \mathrm{X} 3+$ b4X $4+\mathrm{e}$

di mana:

$\mathrm{Y}=$ Persepsi Konsumsi Pangan Non Beras

$\mathrm{X} 1=$ Faktor Budaya

$\mathrm{X} 2=$ Faktor Sosial

$\mathrm{X} 3$ = Pribadi

X4 = Motivasi

$\mathrm{e}=$ Error

Ketetapan fungsi regresi dalam menaksir nilai aktual dapat diukur dengan nilai uji $\mathrm{F}$, uji $\mathrm{t}$, dan nilai koefisien determinasi (R2).

a) Uji Statistik F

Uji statistik $F$ menunjukkan apakah semua variabel independen yang dimasukkan dalam model mempunyai pengaruh secara bersama- sama terhadap variabel dependen (Ghozali:2012). Jadi uji statistik F menunjukan apakah variabel budaya, sosial, pribadi dan motivasi mempunyai pengaruh secara bersama-sama terhadap persepsi konsumsi pangan pokok non beras. 
Pada uji $F$ jika tingkat signifikansi lebih kecil dari 0,05 maka dapat dinyatakan bahwa variabel budaya, sosial, pribadi dan motivasi secara simultan atau bersama-sama mempengaruhi persepsi konsumsi pangan pokok non beras ( untuk tingkat signifikan $=5 \%$ ), maka variabel budaya, sosial, pribadi dan motivasi secara serentak berpengaruh terhadap persepsi konsumsi pangan pokok non beras. Sedangkan jika nilai signifikan lebih besar dari 0,05 maka variable budaya, sosial, pribadi dan motivasi secara serentak tidak berpengaruh terhadap persepsi konsumsi pangan pokok non beras.

b) Uji Statistik t

Uji $t$ digunakan untuk menunjukkan seberapa jauh pengaruh satu variabel penjelas/ independen secara individual dalam menerangkan variasi variable dependen. Ini berarti uji t digunakan untuk menguji signifikansi hubungan antara variabel $\mathrm{X}$ dan $\mathrm{Y}$, apakah variabel $\mathrm{X} 1, \mathrm{X} 2, \mathrm{X} 3$ dan $\mathrm{X} 4$ benarbenar berpengaruhterhadap variabel Y (Persepsi konsumsi pangan non beras) secara terpisah atau parsial. Hipotesis yang digunakan dalam pengujian penelitian ini adalah:

Ho: Variabel-variabel bebas (budaya, sosial, pribadi dan motivasi) tidak mempunyai pengaruh yang signifikan terhadap variabel terikat (persepsi konsumsi pangan pokok non beras).

Ha: Variabel-variabel bebas (budaya, sosial, pribadi dan motivasi) mempunyai pengaruh yang signifikan terhadap variabel terikat (persepsi konsumsi pangan pokok non beras).

$$
\text { Dasar }
$$

keputusannya pengambilan adalah membandingkan angka probabilitas signifikansi, yaitu:

i. Apabila angka probabilitas signifikansi lebih dari 0.05, maka Ho diterima dan Ha ditolak artinya tidak ada pengaruh antara variabel bebas terhadap variabel terikat.

ii. Apabila angka probabilitas signifikansi kurang dari 0.05 , maka Ho ditolak danHa diterima artinya ada pengaruh antara variabel bebas terhadap variabel terikat.

c) Uji Koefisien Determinasi (R2) Uji koefisien determinasi (R2) adalah alat ukur variasi perubahan variabel dependent yang dapat dijelaskan oleh perubahan variabel independent. Nilai R2 yang semakin mendekati 1 , berarti variabel-variabel independen memberikan hampir semua informasi yang dibutuhkan untuk memprediksi variasi variable independen (Sugiyono: 2012).

\section{HASIL DAN PEMBAHASAN}

\section{Karakteristik Responden}

Karakteristik responden ini ditujukan untuk mengetahui bagaimana latar belakang responden. Responden berjumlah 100 sampel yang merupakan warga dari 11 Kecamatan di Kota Depok. Responden juga hanya dikhususkan kepada para Ibu rumah tangga yang diasumsikan sebagai pemegang keputusan untuk urusan pangan dalam keluarga sehingga menjadi acuan anggota keluarganya. Karakteristik responden yang diindentifikasi dalam penelitian ini meliputi usia, pekerjaan, pendidikan, pendapatan, pengeluaran, konsumsi keluarga, pengetahuan pangan pokok non beras, pengetahuan kebijakan one day no rice dan konsumsi selain nasi. 


\section{Uji Asumsi Klasik}

\section{Uji Normalitas}

Uji normalitas adalah pengujian tentang kenormalan distribusi data. Penggunaan uji normalitas karena pada analisis statistik parametik, asumsi yang harus dimiliki oleh data adalah bahwa data tersebut harus terdistribusi secara normal. Maksud data terdistribusi secara normal adalah bahwa data akan mengikuti bentuk distribusi normal (Santosa\&Ashari: 2005).

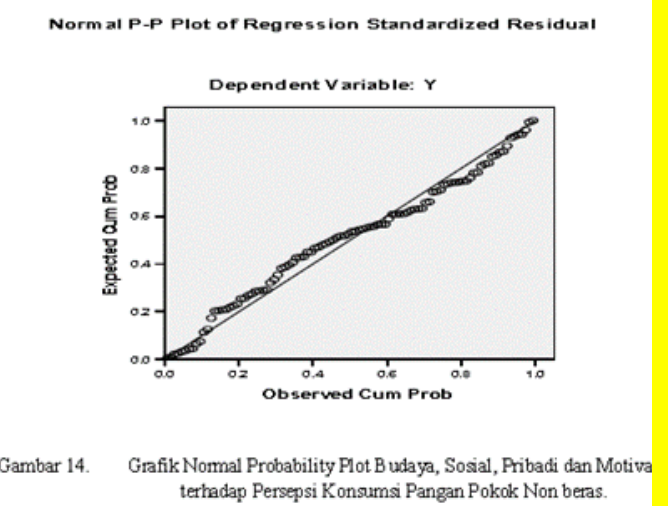

Berdasarkan analisis kurva pada gambar 14, menunjukan bahwa hubungan antara variabel budaya (X1), sosial (X2), pribadi (X3) dan motivasi (X4) terhadap persepsi konsumsi (Y) menunjukan pola distribusi secara normal di mana titik-titik data menyebar di sekitar diagram mengikuti garis diagonal lurus. Jadi, disimpulkan bahwa data yang diolah merupakan data yang berdistribusi normal sehingga uji normalitas terpenuhi.

\section{Uji Multikolineritas}

Uji ini bertujuan untuk menguji apakah model regresi ditemukan adanya korelasi antara variabel bebas (independen). Model regresi yang baik seharusnya tidak terjadi korelasi di antara variabel independen. Jika variabel independen saling berkorelasi, maka variabel-variabel ini tidak ortogonal (Ghozali: 2007). Untuk mendeteksi adanya multikolinearitas, dapat dilihat dari Value Inflation Factor (VIF).

Apabila nilai VIF > 10, terjadi multikolinieritas. Sebaliknya, jika VIF < 10, tidak terjadi multikolinearitas (Wijaya:2009).

Tabel 9. Uji Multikolineritas

\begin{tabular}{|l|r|}
\hline \multicolumn{1}{|c|}{ Model } & Collinearity Statistics \\
\cline { 2 - 2 } & \multicolumn{1}{|c|}{ VFF } \\
\hline (Constant) & 1.011 \\
Budaya & 1.119 \\
Sosial & 1.357 \\
Pribadi & 1.280 \\
Motivasi & \\
\hline Sumber. Olah deta SPSS
\end{tabular}

Berdasarkan tabel 9, didapatkan hasil output data bahwa VIF untuk variabel budaya sebesar 1,011 , sosial sebesar 1,119, pribadi sebesar 1,357 dan motivasi sebesar 1,280. semua nilai koefisien variable VIF $<10$, hal ini berarti bahwa tidak terjadi multikolinieritas yaitu tidak adanya korelasi yang tinggi antar variabel independen dalam model regresi sehingga hubungan antara variabel idependen dan variabel dependen tidak terganggu, dan uji multikolinieritas terpenuhi.

\section{Uji Heteroskedasitas}

Pengujian ini digunakan untuk melihat apakah variabel pengganggu mempunyai varian yang sama atau tidak. Heteroskedastisitas mempunyai suatu keadaan bahwa varian dari residual suatu pengamatan ke pengamatan yang lain berbeda. Salah satu metode yang digunakan untuk menguji ada tidaknya Heterokedastisitas akan mengakibatkan penaksiran koefisienkoefisien regresi menjadi tidak efisien. Hasil penaksiran akan menjadi kurang dari semestinya. 
Heterokedastisitas bertentangan dengan salah satu asumsi dasar regresi linear, yaitu bahwa variasi residual sama untuk semua pengamatan atau disebut homokedastisitas (Gujarati dalam Elmasari: 2010).

Hetroskedasitas dapat dideteksi dengan melihat grafik plot antara nilai prediksi variabel terikat dengan residualnya. Hasil uji hetroskedasitas dapat dilihat pada gambar 15 yang dapat diketahui bahwa tidak terjadi heteroskedastisitas sebab tidak ada pola yang jelas serta titik-titik menyebar di atas dan di bawah angka 0 pada sumbu $\mathrm{Y}$ dan uji heteroskedistisitas terpenuhi.

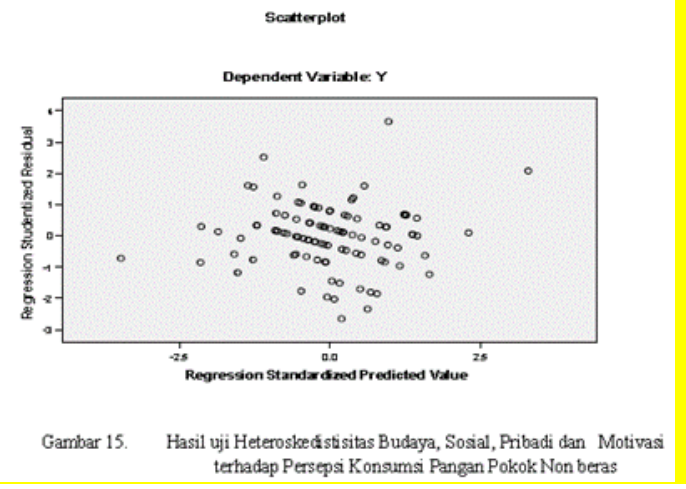

\section{Pengujian Hipotesis}

Hipotesis yang digunakan dalam penelitian ini, diantaranya:

1. Hipotesis variabel Budaya adalah:

Ho1: $\mathrm{p}<0$ (Tidak terdapat pengaruh variabel budaya terhadap persepsi konsumsi pangan

pokok non beras).

$\mathrm{H} 1$ : $\mathrm{p} 0>0$ (Terdapat pengaruh variabel budaya terhadap persepsi konsumsi pangan pokok non beras).

2. Hipotesis variabel sosial adalah: Ho2: $\mathrm{p}<0$ (Tidak terdapat pengaruh variabel sosial terhadap persepsi konsumsi pangan pokok non beras).
$\mathrm{H} 2$ : $\mathrm{p} 0>0$ (Terdapat pengaruh variabel sosial terhadap persepsi konsumsi pangan pokok non beras).

3. Hipotesis variabel pribadi adalah:

Ho3: $\mathrm{p}<0$ (Tidak terdapat pengaruh variabel pribadi terhadap persepsi konsumsi panganpokok non beras).

H3 : p0>0 (Terdapat pengaruh variabel pribadi terhadap persepsi konsumsi pangan pokok non beras).

4. Hipotesis variabel motivasi adalah:

Ho4: $\mathrm{p}<0$ (Tidak terdapat pengaruh variabel motivasi terhadap persepsi konsumsi pangan

pokok non beras).

H4 : p0>0 (Terdapat pengaruh variabel motivasi terhadap persepsi konsumsi pangan

pokok non beras).

5. Hipotesis variabel budaya, sosial, pribadi dan motivasi adalah:

Ho5: $\mathrm{p}<0$ (Tidak terdapat pengaruh variabel budaya, sosial, pribadi dan motivasi secarabersama-sama terhadap persepsi konsumsi pangan pokok non beras).

H5 : p0>0 (Terdapat pengaruh variabel budaya, sosial, pribadi dan motivasi secarabersama-sama terhadap persepsi konsumsi pangan pokok non beras).

Pengujian hipotesis pada penelitian ini menggunakan uji t dan uji F. Uji t untuk mengukur ada atau tidaknya pengaruh masing-masing variabel $\mathrm{X}$ terhadap variabel $\mathrm{Y}$. Sedangkan uji $\mathrm{F}$ digunakan untuk mengukur ada atau tidaknya pengaruh seluruh variabel $X$ secara bersama-sama terhadap variabel Y. 
Uji t

Uji $\mathrm{t}$ digunakan untuk mengetahui adanya pengaruh dan berapa besar pengaruh variabel budaya, sosial, pribadi dan motivasi terhadap persepsi konsumsi pangan pokok non beras. Hasil uji t terhadap variabel budaya, sosial, pribadi dan motivasi dengan persepsi konsumsi pangan pokok non beras dapat dilihat pada tabel 10 .

Tabel 10. Hasil Uji t Pengaruh Variabel Budaya, Sosial, Pribadi dan Motivasi terhadap Persepsi Konsumsi Pangan Pokok Non Beras

\begin{tabular}{|c|c|c|c|}
\hline \multicolumn{2}{|r|}{ Model } & $\mathrm{t}$ & $\mathrm{Sig}$ \\
\hline \multirow[t]{5}{*}{1} & (Constant) & 3.230 & .002 \\
\hline & $\mathrm{X} 1$ & .422 & .674 \\
\hline & $\mathrm{X} 2$ & .464 & .643 \\
\hline & $\mathrm{X}_{3}$ & 2.401 & .018 \\
\hline & $\mathrm{X} 4$ & 2.867 & .005 \\
\hline & & & \\
\hline
\end{tabular}

Hasil pengolahan uji $\mathrm{t}$ pada tabel 10 memperlihatkan bahwa thitung pada variabel budaya sebesar 0,422 dan ttabel 1,66 dengan tingkat signifikansi $5 \%(0,05)$. Hasil yang di dapatkan thitung < ttabel yaitu $0,422>1,66$ adalah tolak $\mathrm{H} 1$ atau terima Ho1. Perumusan tolak Ho1 atau terima $\mathrm{H} 1$ pada uji parsial variabel budaya adalah tidak terdapat pengaruh nyata atau signifikan antara variabel budaya terhadap persepsi konsumsi pangan pokok non beras. Hasil thitung pada variabel sosial sebesar 0,464,nilai tersebut <ttabel sehingga tolak $\mathrm{H} 2$ atau terima $\mathrm{Ho} 2$. perumusan terima $\mathrm{Ho} 2$ pada uji parsial variabel sosial adalah tidak terdapat pengaruh nyata atau signifikan antara variabel sosial terhadap persepsi konsumsi pangan pokok non beras.

Hasil t hitung pada variabel pribadi sebesar 2,401, nilai tersebut > $\mathrm{t}$ tabel sehingga tolak $\mathrm{Ho} 3$ atau terima H3. Perumusan terima H3 pada uji parsial variabel pribadi adalah terdapat pengaruh yang nyata atau signifikan antara variabel pribadi terhadap persepsi konsumsi pangan pokok non beras. Hasil thitung pada variabel motivasi sebesar 2,867, nilai tersebut $>\mathrm{t}$ tabel sehingga tolak Ho4 atau terima $\mathrm{H} 4$. Perumusan terima $\mathrm{H} 4$ pada uji parsial variabel motivasi adalah terdapat pengaruh yang nyata atau signifikan antara variabel motivasi terhadap persepsi konsumsi pangan pokok non beras.

\section{Uji F}

Uji F digunakan untuk mengetahui pengaruh bersama-sama variabel bebas terhadap variabel terikat, di mana Fhitung > Ftabel maka H5 diterima atau secara bersamasama variabel bebas dapat menerangkan variabel terikatnyasecara serentak dan sebaliknya apabila Fhitung $<$ Ftabel maka Ho5 diterima atau secara bersama-sama variabel bebas tidak memiliki pengaruh terhadap variabel terikat. Hasil Uji F terlihat pada tabel 11.

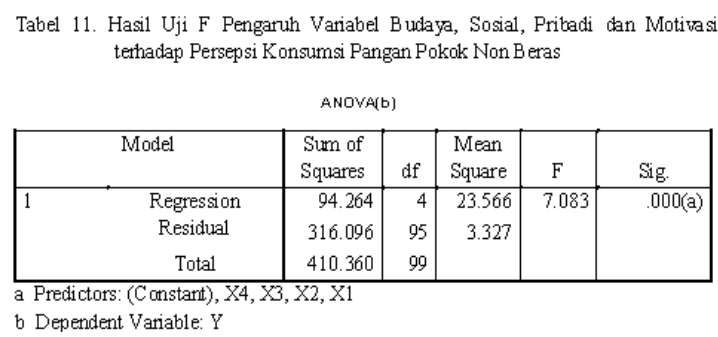

Hasil uji $F$ seperti pada tabel 11 menunjukan bahwa pada tingkat signifikansi 5\% diketahui nilai Ftabel sebesar 2,47 dan nilai Fhitung sebesar 7,083. Nilai Fhitung >Ftabel, maka tolak $\mathrm{Ho5}$ atau terima H5, yaitu adanya pengaruh variabel budaya, sosial, pribadi dan motivasi secara bersama-sama terhadap persepsi konsumsi pangan pokok non beras.

Analisis Regresi Linier Berganda 
Dalam penelitian ini, yang menjadi variabel terikat (Y) adalah persepsi konsumsi pangan pokok nonberas. Sedangkan yang menjadi variabel bebas (X) adalah faktorfaktor yang mempengaruhi yaitu budaya (X1), sosial (X2), pribadi (X3) dan motivasi (X4). Data variabel-variabel tersebut dianalisis dengan terlebih dahulu diubah menjadi bentuk dengan menggunakan skala likert untuk memudahkan dalam menganalisnya. Berdasarkan hasil dari analisis regresi linier berganda dengan menggunakan alat bantu SPSS, didapatkan model persamaan regresi linier berganda seperti yang dapat dilihat pada Tabel 12.

\begin{tabular}{|c|c|c|c|c|c|}
\hline \multirow[t]{2}{*}{ Model } & \multicolumn{2}{|c|}{$\begin{array}{l}\text { Unstandardized } \\
\text { Coefficients }\end{array}$} & \multirow{2}{*}{$\begin{array}{c}\text { Standardized } \\
\text { Coefficients }\end{array}$} & \multirow[t]{2}{*}{$\mathrm{T}$} & \multirow[t]{2}{*}{ Sig. } \\
\hline & $\mathrm{B}$ & Std Error & & & \\
\hline (Constant) & 9.190 & 2.845 & & 3.230 & .00 \\
\hline Budaya & .033 & .078 & .038 & .422 & .67 \\
\hline Sosial & .038 & .083 & .044 & .464 & .64 \\
\hline Pribadi & .268 & .112 & .252 & 2.401 & .01 \\
\hline Motivasi & .268 & .093 & .292 & 2.867 & .00 \\
\hline R Square & & & & & .23 \\
\hline Fhitung & & & & & 7.08 \\
\hline \multicolumn{6}{|l|}{ Ftabel $=2.47$} \\
\hline Ttabel $=1.66$ & & & & & \\
\hline
\end{tabular}

Berdasarkan tabel 12, model persamaan regresi linier berganda yang telah dijabarkan pada metodologi penelitian, maka persemaan regresi tersebut, yaitu:

$\mathrm{Y}=9,190+0,033 \mathrm{X} 1+0,038 \mathrm{X} 2+$ $0,268 \mathrm{X} 3+0,268 \mathrm{X} 4+\mathrm{e}$

Keterangan :

$\mathrm{Y}$ : persepsi konsumsi pangan pokok non beras

$\mathrm{X} 1$ : Budaya

$\mathrm{X} 2$ : Sosial

X3 : Pribadi

X4 : Motivasi

\section{Pengaruh Budaya terhadap Persepsi Konsumsi Pangan Pokok non Beras}

Berdasarkan hasil analisis menggunakan regresi linier berganda pada tabel 12, variabel faktor sbudaya (X1), berpengaruh positif tidak signifikan terhadap persepsi pangan pokok non beras. Dengan konstanta sebesar 9,190 menyatakan bahwa apabila tidak ada kenaikan dari nilai variabel budaya (X1), maka nilai persepsi konsumsi pangan pokok non beras (Y) adalah 9,190. Koefisien regresi sebesar 0,033 menyatakan bahwa semakin menerimanya masyarakat untuk konsumsi pangan non beras maka akan ada penambahan satu satuan atau nilai budaya dan memberikan kenaikan nilai sebesar 0,033 satuan. Pada tingkat kepercayaan 95 persen, variabel sosial konsumen berpengaruh positif tidak signifikan terhadap persepsi konsumsi pangan pokok non beras. Ini ditunjukkan dengan nilai signifikansi sebesar 0.647 (>0,05).

Hal ini berarti jika faktor budaya yang ada di sekitar masyarakat semakin baik maka akan mengakibatkan semakin menurun persepsi konsumsi pangan pokok non beras. Hasil ini dapat dikatakan bahwa faktor budaya di masyarakat sulit untuk mengubah konsumsi pangan pokok beras menjadi pangan pokok non beras. Seperti terlihat pada tabel 13 bagaimana masyarakat yang kurang adaftif lewat pendekatan budaya terhadap pangan pokok non beras dengan persentase mencapai 69\%. Data di atas didukung oleh pernyataan dalam butir-butir kuisioner yang dibagi ke dalam lima kelompok berdasarkan adaptasinya lewat faktor budaya terhadap pangan pokok non beras. Menggunakan teori dari Ralph Klimann (dalam Tika: 2006) yang menggambarkan budaya 
adaptif merupakan sebuah budaya dengan pendekatan.

Tabel 13. Hasil Analisis Data Frekuensi Nilai Variabel B udaya
\begin{tabular}{|l|c|c}
\hline & Frekuensi & Persentase \\
\hline Sangat adaptif & 1 & $1 \%$ \\
\hline Adaptif & 27 & $27 \%$ \\
\hline Kurang Adaptif & 69 & $69 \%$ \\
\hline Tidak adaptif & 3 & $3 \%$ \\
\hline Sangat Tidak adaptif & 0 & $0 \%$ \\
\hline Jumlah & 100 & $100 \%$ \\
\hline Sumber : Data O1ah Ex cel
\end{tabular}

Terlihat dari tabel 13. Budaya masyarakat cenderung kurang adaptif, karena sebanyak 69 responden menyatakan kurang adaptif terhadap hal baru seperti pangan pokok non beras. Sebesar tiga responden tidak adaptif terhadap pangan pokok non beras. Tetapi sebanyak 27 responden adaptif dengan adanya hal baru yaitu konsumsi pangan pokok non beras, dan satu responden merasa sangat adaftif. Hal ini dikarenakan konsumsi pangan pokok beras sudah seakan melekat dalam kehidupan bermasyarakat responden sehingga selain nasi dianggap sebagai sesuatu yang bukan pokok dan hanya sebatas barang substitusi. Namun ini sedikit demi sedikit memudar dengan adanya pemahaman baru dimasyarakat, dibuktikan walau dengan hanya 28 responden yang adaptif dan sangat adaftif dengan konsumsi pangan pokok non beras.

\section{Pengaruh Sosial terhadap Persepsi Konsumsi Pangan Pokok non Beras}

Pengaruh variabel faktor sosial (X2) seperti pada tabel 12, berpengaruh positif tidak signifikan terhadap persepsi pangan pokok non beras. Dengan konstanta sebesar 9,190 menyatakan bahwa apabila tidak ada kenaikan dari nilai variabel sosial (X2), maka nilai persepsi konsumsi pangan pokok non beras (Y) adalah 9,190. Koefisien regresi sebesar 0,038 menyatakan bahwa semakin menerimanya masyarakat untuk konsumsi pangan non beras maka akan ada penambahan satu satuan atau nilai sosial dan memberikan kenaikan nilai sebesar 0,038 satuan. Pada tingkat kepercayaan 95 persen, variabel sosial konsumen berpengaruh positif tidak signifikan terhadap persepsi konsumsi pangan pokok non beras. Ini ditunjukkan dengan nilai signifikansi sebesar $0.643(>0,05)$. Hal ini berarti jika faktor sosial yang ada di sekitar masyarakat semakin baik maka akan mengakibatkan semakin menurun persepsi konsumsi pangan pokok non beras. Karena pengaruh lingkungan kerja, teman dan kelompok keagamaan tidak bisa menganggap pangan pokok non beras sebagai pangan pokok.

Pada tabel 14 juga dinyatakan bahwa masyarakat masih belum bisa menerima pangan pokok non beras, bahkan senilai $72 \%$ kurang menerima terhadap pangan pokok non beras. Pada variable faktor sosial, masyarakat masih kurang menerima terhadap konsumsi pangan pokok non beras. Persepsi terhadap sesuatu hal yang baru, sepertidiketahui, seseorang bisa dipengaruhi oleh kelompok yang memiliki hubungan dekat ataupun tidak. Menurut Kotler dan Keller (2009), perilaku responden dipengaruhi oleh faktor - faktor sosial seperti kelompok acuan atau referensi, keluarga serta peran dan status sosial sehingga lewat itulah masyarakat bisa menerima atau tidaknya hal-hal baru tersebut. Tabel 14 menunjukkan skor dari indicatorindikator faktor sosial terhadap persepsi konsumsi pangan pokok non beras. 


Tabel 14. Hasil Aralisis Data Frekuensi Nilai Variabel Sosial
\begin{tabular}{|l|c|c}
\hline & Frekuensi & Persentase \\
\hline Sangat menerima & 0 & $0 \%$ \\
\hline Menerima & 22 & $22 \%$ \\
\hline Kurang menerima & 72 & $72 \%$ \\
\hline Menolak & 6 & $6 \%$ \\
\hline Sanagt menolak & 0 & $0 \%$ \\
\hline Jumlah & 100 & $100 \%$ \\
\hline Sumber: Data Olah Excel
\end{tabular}

Pada tabel 14, masyarakat yang menerima adanya pergantian pangan pokok beras menjadi non beras sebesar 22 responden. Sedangkan yang kurang menerima sebanyak 22 responden. Responden juga menerima pangan pokok non beras hanya pada beberapa indikator seperti dalam butir X24 dan X25 kuisioner yaitu peran keluarga dan peran status sosial yang terlihat lebih diterima dibandingkan butir-butir kuisioner lainnya. Dengan demikian persepsi masyarakat tentang mengkonsumsi pangan pokok non beras lebih cenderung kurang menerima pergantian pangan pokok melewati beberapa agen sosialisasi seperti teman dan kelompok keagamaan.

\section{Pengaruh Pribadi terhadap Persepsi Konsumsi Pangan Pokok non Beras}

Pengaruh faktor pribadi (X3) berpengaruh positif dan signifikan terhadap pangan pokok non beras. Dengan konstanta sebesar 9,190 menyatakan bahwa jika tidak ada kenaikan dari nilai variabel pribadi (X3) maka nilai perilaku konsumsi pangan pokok non beras (Y) adalah 9,190. Koefisien regresi faktor pribadi sebesar 0,268 menyatakan bahwa setiap penambahan keterbukaan masyarakat terhadap perilaku konsumsi pangan pokok non beras dengan nilai satu satuan atau nilai factor pribadi maka akan memberikan nilai sebesar 0,268. Nilai koefisien regresi pribadi (X3) sebesar 0,268 dengan signifikansi
$0.018<5 \%$ berarti signifikan untuk memprediksi perilaku konsumsi pangan pokok non beras di Wilayah Kota Depok.

Dengan ini berarti faktor pribadi (X3) berpengaruh positif dan signifikan terhadap persepsi pangan pokok non beras (Y). Hal ini berarti faktor pribadi seperti gaya hidup dan siklus hidup seseorang serta kondisi ekonomi mempengaruhi pergantian pangan pokok dengan pangan pokok non beras. Pengaruh faktor pribadi yang signifikan juga terlihat dengan sikap keterbukaan responden terhadap pangan pokok non beras. Sikap terbuka (openmindedness) amat besar pengaruhnya dalam menumbuhkan komunikasi interpersonal yang efektif. Lawan dari sikap terbuka adalah dogmatisme. Brooks dan Emmert (1977) mengkontraskan karakteristik orang yang bersikap terbuka dengan karakteristik orang yang bersikap tertutup, sebagai berikut:

Sikap terbuka:

1. Menilai pesan secara objektif dengan menggunakan data dan keajegan logika

2. Membedakan dengan mudah, melihat nuansa dan sebagainya

3. Berorientasi pada isi

4. Mencari informasi dari berbagai sumber

5. Lebih bersifat profesional dan bersedia merubah keperceyaannya

Sikap tertutup:

1. Menilai pesan berdasarkan motif-motif pribadi

2. Berpikir simplistis, artinya berpikir hitam putih (tanpa nuansa)

3. Bersandar lebih banyak pada sumber pesan daripada isi pesan

4. Mencari informasi tentang kepercayaan orang lain dari 
sumbernya sendiri, bukan dari sumber kepercayaan orang lain

5. Secara kaku mempertahankan dan memegang teguh sistem kepercayaannya

Sikap keterbukaan dalam aplikasinya terhadap persepsi konsumsi pangan pokok non beras tercantum dalam tabel 15 .

Tabel 15. Hasil Aralisis Data Frekuensi Nilai Variabel Pribadi
\begin{tabular}{|l|c|c}
\hline & Frekuensi & Persentase \\
\hline Sangat Terbuka & 0 & $0 \%$ \\
\hline Terbuka & 59 & $59 \%$ \\
\hline Kurang terbuka & 41 & $41 \%$ \\
\hline Tertutup & 0 & $0 \%$ \\
\hline Sangat tertutup & 0 & $0 \%$ \\
\hline Jumlah & 100 & $100 \%$ \\
\hline Sumber : Data olah excel
\end{tabular}

Ditinjau dari tabel 15. Faktor pribadi dibagi menjadi lima bagian yaitu pribadi sangat terbuka,terbuka, kurang terbuka, tertutup dan tertutup berdasarkan dengan teori yang dikemukakan oleh Brooks dan Emmert (1977). Pribadi terbuka sebanyak 59 responden, sedangkan kurang terbuka sebanyak 41 responden. Dengan demikian lebih banyak masyarakat yang memiliki pribadi yang terbuka dengan sikap yang menerima pesan tentang konsumsi pangan ,dengan pemikiran dan logika yang terbuka terhadap pergantian pangan pokok beras menjadi pangan pokok non beras. Kekurang terbukaan bisa disebabkan oleh pribadi yang terbentuk dalam lingkungan yang homogen dalam konsumsi pangan pokok juga keterbukaan bisa disebabkan hal yang sama. Namun, sikap ini juga banyak dipengaruhi oleh latar belakang pribadi responden seperti pendidikan, gaya hidup dan lingkungan kerja sehingga memungkinkan ada pengetahuan baru yang dinamis sehingga merubah perilaku konsumsi.

Dalam indikator kuisioner variabel pribadi, sikap keterbukaan responden lebih dominan dalam butir
X32 dan X34 yaitu karena alasan kesehatan dan gaya hidup bervariatif yang membuat masyarakat terbuka terhadap pangan pokok non beras hingga diatas $70 \%$ dan butir lainnya cukup memberikan gambaran positif terhadap keterbukaan responden.

\section{Pengaruh Motivasi terhadap Persepsi Konsumsi Pangan Pokok nonBeras}

Pengaruh faktor motivasi (X4) secara signifikan berpengaruh terhadap persepsi konsumsi pangan pokok non beras (Y). dengan konstanta sebesar 9,190 menyatakan bahwa jika tidak ada kenaikan dari variabel motivasi (X4), maka nilaipersepsi konsumsi pangan pokok non beras (Y) adalah 9,190. Koefisien regresisebesar 0,268 menyatakan bahwa semakin tinggi masyarakat yang termotivasi makaakan ada penambahan satu satuan nilai motivasi sebesar 0,268 terhadap persepsikonsumsi pangan pokok non beras.

Nilai koefisien movivasi (X4) sebesar 0.268 dengan signifikansi 0.005 atau0.005 \% < 5\% berarti signifikan untuk memprediksi persepsi konsumsi pangan pokoknon beras di Kota Depok. Hal ini berarti jika motivasi semakin baik terhadap persepsipangan pokok non beras, maka akan mengakibatklan semakin tinggi pula polakonsumsi pangan pokok non beras.

Faktor motivasi akan sangat berpengaruh jika hal itu terus berlangsung sepertiyang pernah diucapkan Atkinson (Linda: 2004) yang mengatakan bahwa FreeChoise, adalah bahwa individu yang memiliki motivasi berprestasi tinggi menyukaiaktivitas-aktivitas atas keberhasilannya sehingga selalu berusaha untuk meningkatkansegala 
kemungkinan untuk berprestasi oleh karena kemampuan pengalamankeberhasilannya yang lebih banyak sehingga kendati mengalami kagagalan masihtetap tersirat untuk berhasil.

\section{KESIMPULAN DAN SARAN}

\section{Kesimpulan}

Berdasarkan hasil penelitian dan analisis data yang dilakukan, maka dapat disimpulkan sebagai berikut :

1. Hasil penelitian ini menunjukan karakteristik responden berusia terbanyak pada kisaran 30-39 tahun dengan pekerjaan terbanyak pada ibu rumah tangga. Sebagian besar responden hanya berpendidikan tamat sekolah menengah atas dan sebagian besar berpendapatan diangka Rp. 2.500.000- Rp. 3.500.000. Makanan pokok yang dikonsumsi responden adalah nasi walaupun sebagian besar sudah mengetahui tentang pangan pokok non beras dan mengetahui program diversifikasi pangan yang diterapkan dalam kebijakan one day no rice di Kota Depok.

2. Budaya merupakan variabel yang kurang dapat mendorong masyarakat untuk mengkonsumsi pangan pokok non beras. Pendekatan lewat budaya bisa dilakukan jika dalam satu komunitas masyarakat mengkonsumsi pangan pokok non beras bersama-sama seperti dalam salah satu indikator yang bernilai positif terhadap hal tersebut.
3. Sosial merupakan variabel yang kurang dapat mendorong masyarakat untuk mengkonsumsi pangan pokok non beras. Walaupun bernilai positif tapi tidak signifikan dalam mempengaruhi masyarakat. Keluarga dan status sosial merupakan satu-satunya indikator di variabel ini yangbernilai positif dalam mengajak masyarakat supaya dapat menerima pangan pokok non beras.

4. Pribadi merupakan salah satu indikator yang dapat membawa masyarakat terbuka terhadap pangan pokok non beras di penelitian ini. Indikator seperti alasan kesehatan dan gaya hidup menjadi faktor tertinggi.

5. Motivasi merupakan variabel yang berpengaruh dan signifikan dalam memotivasi masyarakat untuk dapat mengkonsumsi pangan pokok non beras. Indikator seperti ketertarikan akan kemasan dan olahan pangan non beras, asupan gizi yang beragam dan kebijakan one day no rice merupakan hal yang paling mempengaruhi.

6. Secara bersama-sama, budaya, sosial, pribadi dan motivasi sebagaimana telah dibahas dalam uji $F$ kesemuanya berpengaruh terhadap persepsi konsumsi pangan pokok non beras. Variabel motivasi menjadi yang paling berpengaruh dibandingnkan dengan variabel lainnya.

\section{Saran}

Dari hasil penelitian ini, maka saran-saran yang dapat penulis berikan adalah sebagai berikut: 
1. Dari segi budaya ajakan untuk mengkonsumsi pangan pokok non beras seharusnya melewati komunitas-komunitas

masyarakat sehinggu bisa menjadi contoh bagi masyarakat dalam mengkonsumsinya. Dari segi sosial pendekatan melalui keluarga yang seharusnya lebih diintensifkan. Dari segi pribadi dan motivasi, sosialisasi pangan pokok non beras darisegi produk, kandungan dan kesehatan seharusnya bisa lebih ditingkatkan. Didorong dengan peningkatan sosialisasi kebijakan one day no rice sampai lapisan pemerintahan terbawah.

2. Perlu adanya penelitian lanjutan tentang persepsi konsumsi pangan pokok non beras dengan penambahan variabel-variabel selain variabel budaya, sosial, pribadi dan motivasi.

\section{DAFTAR PUSTAKA}

Arifin, Bustanul. 2007. Diagnosis Ekonomi Politik Pangan dan Pertanian. Jakarta:Raja Grafindo Persada.

Asngari, 1984. Persepsi Direktur Penyuluhan Tingkat Karesidenan dan KepalaPenyuluh Pertanian terhadap Peranan dan Fungsi Lembaga PenyuluhPertanian di Negara bagian Texas Amerika Serikat. Media Peternakan Vol 9No. 2 Fakultas Peternakan. Bogor: Institut Pertanian Bogor.

Atkinson, Rita Dkk. 1997. Pengantar Psikologi I Edisi ke Delapan. Jakarta: Erlangga.

Bodroastuti, Abdul GhoniI Tri. 2011. Pengaruh Faktor Budaya,
Sosial, Pribadi DanPsikologi Terhadap Perilaku Konsumen Pada Pembelian Rumah diPerumahan Griya Utama Banjardowo. Skripsi. UNDIP. Semarang.

Brook, W.D. and P Emmert. 1997. Speech Communication. Dubuque: Wm.C.

BrownBrooks, R.

Budiningsih, Rini. 2009. FaktorFaktor yang Berpengaruh Terhadap

DiversifikasiKonsumsi Pangan Non-Beras di Kabupaten Magelang. $\quad$ Skripsi. UNDIP.Semarang.

Engel JF, Blackwell RD, dan Miniard PW. 1995. Consumer Behavior 8 th Ed. ForthWorth, Texas: The Dryden Press.

Ghozali, Imam. 2006. Aplikasi Analisis Multivarite dengan SPSS, Cetakan Keempat.Semarang: Badan Penerbit Universitas Diponegoro,

Gujarati, Damodar \& Elmasari. $2003 . \quad$ Dasar-Dasar Ekonometrika. Jakarta: Erlangga.

Hafsah J. 2006. Pertanian dan Pangan. Di dalam: Krisnamurthi dkk, editor.Revitalisasi Pertanian dan Dialog Peradaban. Jakarta: Penerbit Buku Kompas.

Handoko, T. Hani. 2012. Manajemen Personalia dan Sumber Daya Manusia.Yogyakarta: BPFE

Hardinsyah. 2004. Gizi Terapan, PAU Pangan dan Gizi IPB. Bogor.

Harper, L. J. et al. 1986. Pangan, Gizi dan Pertanian.Penerjemah Suhardjo, Jakarta:UIPress. 
Jhamtani, Hira. 2008. Lumbung Pangan: Menata Ulang Kebijakan Pangan.Yogyakarta: INSISTPress.

Koentjaraningrat. 2000. Kebudayaan Mentalitas dan Pembangunan (cetakankesembilan belas), Jakarta: PT. Gramedia Pustaka Utama.

* Alamat Korespondensi :

elpawati@gmail.com 
